\title{
Pseudoalteromonas byunsanensis sp. nov., isolated from tidal flat sediment in Korea
}

Correspondence

Jongsik Chun

jchun@snu.ac.kr

\author{
Yoon-Dong Park, ${ }^{1}$ Keun Sik Baik, ${ }^{2}$ Hana Yi, ${ }^{1}$ Kyung Sook Bae ${ }^{3}$ \\ and Jongsik Chun ${ }^{1}$
}

\author{
${ }^{1}$ School of Biological Sciences and Institute of Microbiology, Seoul National University, \\ Kwanak-gu, Seoul 151-742, Republic of Korea \\ ${ }^{2}$ Department of Biology, College of Natural Sciences, Sunchon National University, Sunchon \\ 540-742, Republic of Korea \\ ${ }^{3}$ Korean Collection for Type Cultures, Korea Research Institute of Bioscience and \\ Biotechnology, Taejon 305-600, Republic of Korea
}

\begin{abstract}
A Gram-negative, motile, strictly aerobic, violet-pigment-producing bacterium, designated strain FR1 $199^{\top}$, was isolated from tidal flat sediment of Byunsan, South Korea. Phylogenetic analysis of the $16 \mathrm{~S}$ rRNA gene sequence revealed that strain FR1 $199^{\top}$ represents a distinct line of descent within the genus Pseudoalteromonas. The phenotypic features of strain FR $1199^{\top}$ were similar to those of Pseudoalteromonas phenolica and Pseudoalteromonas luteoviolacea, but several physiological and chemotaxonomical properties readily distinguished strain $\mathrm{FR} 1199^{\top}$ from these species. Major fatty acids were straight-chain saturated $\left(\mathrm{C}_{16: 0}\right)$ and monounsaturated $\mathrm{C}_{18: 1} \omega 7 \mathrm{c}$ fatty acids. The DNA G $+\mathrm{C}$ content was $39 \mathrm{~mol} \%$. On the basis of polyphasic evidence, it is concluded that the isolate represents a novel species within the genus Pseudoalteromonas, for which the name Pseudoalteromonas byunsanensis sp. nov. is proposed. The type strain is FR $1199^{\top}\left(=\mathrm{JCM} 12483^{\top}=\right.$ KCTC $\left.12274^{\top}\right)$.
\end{abstract}

The genus Alteromonas, originally described by Baumann et al. (1972) for marine aerobic, Gram-negative, nonfermentative, polarly flagellated bacteria, was later divided into two genera, Alteromonas and Pseudoalteromonas, on the basis of phylogenetic analysis (Gauthier et al., 1995). The genus Pseudoalteromonas currently comprises 33 species (Gauthier, 1976, 1977, 1982; Gauthier \& Breittmayer, 1979; Novick \& Tyler, 1985; Romanenko et al., 1995, 2003a; Ivanova et al., 1996, 1998, 2000, 2001, 2002a, b, c, d, 2004; Bozal et al., 1997; Bowman, 1998; Holmström et al., 1998; Sawabe et al., 1998, 2000; Venkateswaran \& Dohmoto, 2000; Egan et al., 2001; Isnansetyo \& Kamei, 2003; Kobayashi et al., 2003). In the course of our study on marine microbial diversity, a pseudoalteromonad, designated strain FR1199 ${ }^{\mathrm{T}}$, was isolated from a tidal flat sediment sample and was the subject of a polyphasic taxonomic investigation. On the basis of our evidence, strain FR $1199^{\mathrm{T}}$ represents a novel species in the genus Pseudoalteromonas.

Published online ahead of print on 16 September 2005 as DOI 10.1099/ijs.0.63750-0.

Abbreviation: ASW, artificial sea water.

The GenBank/EMBL/DDBJ accession number for the 16S rRNA gene sequence of Pseudoalteromonas byunsanensis sp. nov. FR1199' is DO011289.
A marine sediment sample was collected from the Korean tidal flat of Byunsan in South Korea $\left(35^{\circ} 34^{\prime} 52 \cdot 3^{\prime \prime} \mathrm{N} 126^{\circ}\right.$ $30^{\prime} 51 \cdot 3^{\prime \prime} \mathrm{E}$ ) in August 2002. The sample was diluted with sterilized artificial sea water (ASW; Lyman \& Fleming, 1940), spread onto a plate containing marine agar 2216 (MA; Difco) and incubated at $25^{\circ} \mathrm{C}$ for 3 weeks. The isolate was routinely cultured on MA and maintained as a glycerol suspension $(20 \% \mathrm{v} / \mathrm{v})$ at $-80{ }^{\circ} \mathrm{C}$.

Bacterial DNA preparation, PCR amplification and sequencing of the 16S rRNA gene were carried out as described previously (Chun \& Goodfellow, 1995). The resultant sequence of strain FR $1199^{\mathrm{T}}$ was aligned manually against sequences obtained from GenBank. Phylogenetic trees were inferred from the regions available for all sequences (positions 43-1438; Escherichia coli numbering system) using the Fitch-Margoliash (Fitch \& Margoliash, 1967), maximum-parsimony (Fitch, 1971) and neighbour-joining (Saitou \& Nei, 1987) methods. Evolutionary distance matrices were generated according to Jukes \& Cantor (1969). The resultant neighbour-joining tree topology was evaluated by bootstrap analyses (Felsenstein, 1985) based on 1000 resamplings. Alignment and phylogenetic analyses were carried out using the jPHYDIT program (http://chunlab.snu.ac.kr/jphydit/; Jeon et al., 2005) and PAUP 4.0 (Swofford, 1998) as described previously (Chun et al., 2000). 
Preliminary sequence comparison with $16 \mathrm{~S}$ rRNA gene sequences held in GenBank indicated that our isolate was closely related to the genus Pseudoalteromonas. The newly determined sequence was then aligned manually against representatives of the genus Pseudoalteromonas using information on bacterial 16S rRNA secondary structures. Strain FR1199 ${ }^{\mathrm{T}}$ showed low levels of $16 \mathrm{~S}$ rRNA gene sequence similarity to other pseudoalteromonads. The highest similarity was found with Pseudoalteromonas rubra ATCC $29570^{\mathrm{T}}(97 \cdot 4 \%)$, followed by Pseudoalteromonas mariniglutinosa NCIMB $1770^{\mathrm{T}}(97 \cdot 2 \%)$, Pseudoalteromonas luteoviolacea NCIMB $1893^{\mathrm{T}}(96 \cdot 7 \%)$ and Pseudoalteromonas piscicida ATCC $15057^{\mathrm{T}}(96 \cdot 6 \%)$. Our isolate formed an independent phyletic line in the Pseudoalteromonas clade in the comprehensive phylogenetic analysis (Fig. 1), to which two species (P. mariniglutinosa and $P$. luteoviolacea) showing $>97 \% 16 \mathrm{~S}$ rRNA similarities were not phylogenetically related. It is clear from the phylogenetic analysis that the tidal flat isolate FR1199 ${ }^{\mathrm{T}}$ represents a novel species in the genus Pseudoalteromonas.

Morphological characteristics were observed by differential interference microscopy (Nikon) and scanning electron microscopy (JEOL) using cells grown at $25^{\circ} \mathrm{C}$ for 3 days. Motility was examined using wet mounts. The $\mathrm{pH}$ range ( $\mathrm{pH} 3-12$ ) for growth was determined using MA. $\mathrm{Na}^{+}$ requirement and tolerance of $0-11 \%(\mathrm{w} / \mathrm{v}) \mathrm{NaCl}$ were determined using synthetic ZoBell medium (ZoBell, 1941; $15 \mathrm{~g}$ Bacto agar, $5 \mathrm{~g}$ Bacto peptone, $1 \mathrm{~g}$ yeast extract, $0 \cdot 1 \mathrm{~g}$ ferric citrate $1^{-1}$ distilled water) prepared on an ASW base, supplemented with appropriate amounts of $\mathrm{NaCl}$.

Growth at various temperatures was examined on MA at $4-50^{\circ} \mathrm{C}$. Growth under anaerobic conditions was checked in an anaerobic chamber $\left[1 \%(\mathrm{v} / \mathrm{v}) \mathrm{CO}_{2}, 10 \%(\mathrm{v} / \mathrm{v}) \mathrm{H}_{2}\right.$, $80 \%(\mathrm{v} / \mathrm{v}) \mathrm{N}_{2}$; Sheldon Manufacturing] using anaerobically prepared MA. Catalase and oxidase activities were determined using $3 \%(\mathrm{v} / \mathrm{v})$ hydrogen peroxide and Kovacs reagent (Kovacs, 1956), respectively. Other biochemical tests were performed using API 20NE and API 20E kits (bioMérieux). Enzyme activities were tested using an API ZYM kit (bioMérieux) following the manufacturer's instructions. Strips were inoculated with a heavy bacterial suspension in ASW or AUX medium (bioMérieux) supplemented with $2 \%(\mathrm{w} / \mathrm{v})$ sea salts. The results of biochemical and physiological tests are given in Table 1

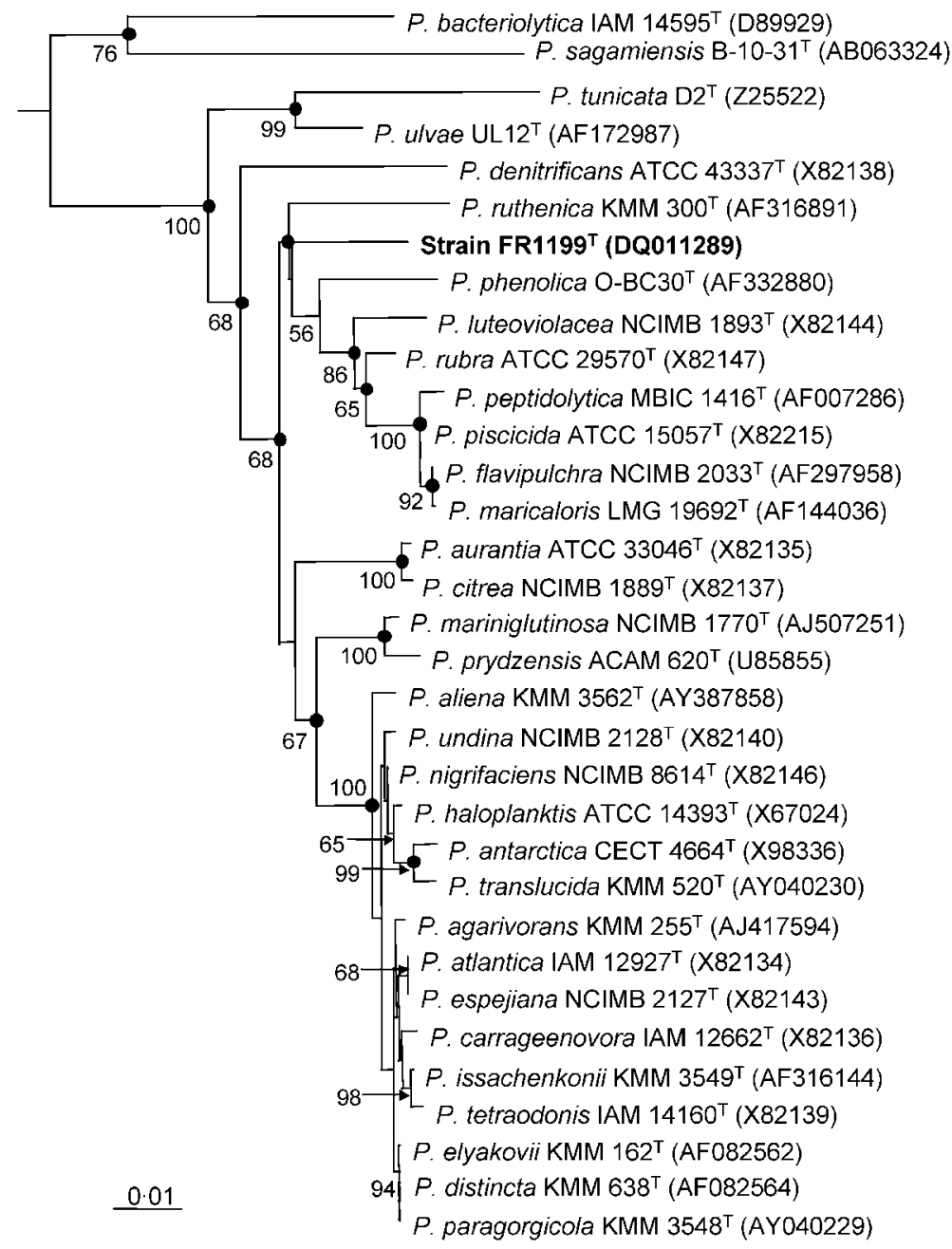

Fig. 1. Neighbour-joining tree based on nearly complete $16 \mathrm{~S}$ rRNA gene sequences showing relationships between strain FR1 $199^{\top}$ and other species of the genus Pseudoalteromonas. Percentage bootstrap values $(>50 \%, 1000$ resamplings) are given at branch points and solid circles indicate that the corresponding nodes (groupings) are also recovered in Fitch-Margoliash and maximum-parsimony trees. Vibrio cholerae ATCC $14035^{\top}$ was used as an outgroup (not shown). Bar, 0.01 nucleotide substitutions per position. 
Table 1. Characteristics that differentiate strain $F R 1199^{\top}$ from related Pseudoalteromonas species

Strains: 1, strain FR1199 ${ }^{\mathrm{T}}$; 2, P. phenolica O-BC30 ${ }^{\mathrm{T}}$; 3, P. luteoviolacea NCIMB $1893^{\mathrm{T}}$; 4, P. piscicida ATCC 15057 ${ }^{\mathrm{T}}$; 5, P. rubra ATCC $29570^{\mathrm{T}}$; 6, P. peptidolytica MBIC $1416^{\mathrm{T}}$; 7, P. flavipulchra NCIMB $2033^{\mathrm{T}}$; 8, P. maricaloris LMG $19692^{\mathrm{T}}$; 9, P. citrea NCIMB $1889^{\mathrm{T}}$; 10 , P. aurantia DSM $6057^{\mathrm{T}} ; 11$, P. ruthenica KMM $300^{\mathrm{T}} ; 12$, P. mariniglutinosa NCIMB $1770^{\mathrm{T}}$. Data from this and earlier studies $($ Gauthier, 1976 ; Novick \& Tyler, 1985; Gauthier et al., 1995; Ivanova et al., 1998, 2002a, 2002d; Venkateswaran \& Dohmoto, 2000; Isnansetyo \& Kamei, 2003; Romanenko et al., 2003b). +, Positive; -, negative; ND, no data available.

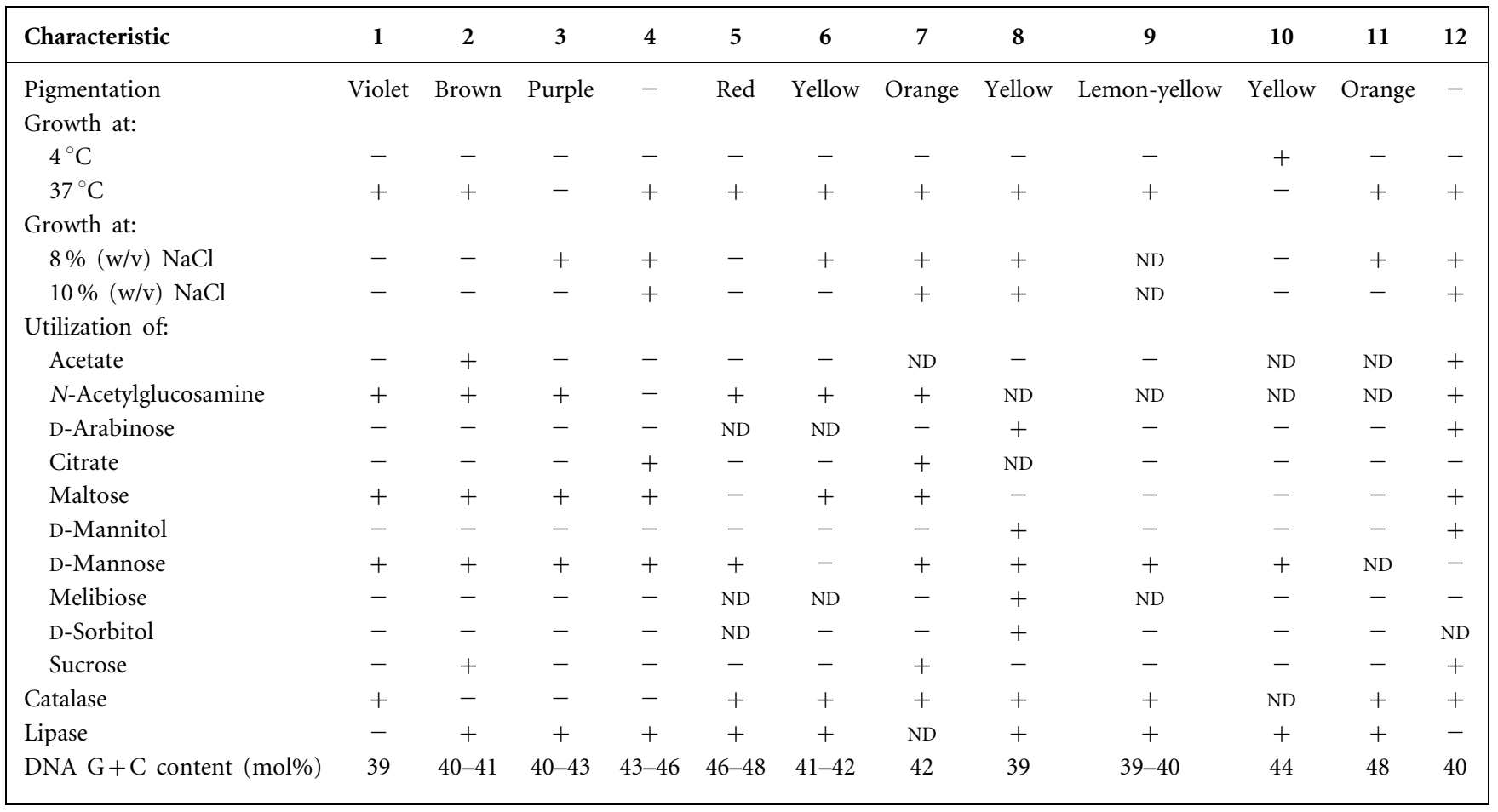

and the species description. Our isolate can be readily differentiated from other phylogenetically related species by several phenotypic properties as shown in Table 1.

Cellular fatty acids of strain FR1199 ${ }^{\mathrm{T}}$ were analysed as methyl esters by GLC using the Microbial Identification System (MIDI). Fatty acid methyl esters were prepared from biomass grown on $\mathrm{MA}$ at $30^{\circ} \mathrm{C}$ for 2 days. The $\mathrm{G}+\mathrm{C}$ content of the DNA was determined by using the thermal denaturation method of Marmur \& Doty (1962). The major cellular fatty acids of the strain FR1199 ${ }^{\mathrm{T}}$ were $\mathrm{C}_{16: 0}(27 \cdot 6 \pm 0.4 \%)$, $\mathrm{C}_{16: 1} \omega 7 c$ and/or iso- $\mathrm{C}_{15: 0} 2-\mathrm{OH}(21 \cdot 7 \pm 1 \cdot 2 \%)$ (summed feature 3$)$ and $\mathrm{C}_{18: 1} \omega 7 c(23 \cdot 3 \pm 0 \cdot 5 \%)$. In addition, $\mathrm{C}_{12: 0}$ $(1 \cdot 1 \pm 0 \cdot 1 \%), \mathrm{C}_{10: 0} 3-\mathrm{OH}(4 \cdot 0 \pm 0 \cdot 3 \%), \mathrm{C}_{12: 0} 3-\mathrm{OH}(3 \cdot 4$ $\pm 0 \cdot 2 \%)$, iso- $\mathrm{C}_{16: 0} 3-\mathrm{OH}(2 \cdot 8 \pm 0 \cdot 6 \%), \mathrm{C}_{18: 0} \omega 6 c(2 \cdot 2 \pm$ $0 \cdot 2 \%), \mathrm{C}_{17: 0}(1 \cdot 6 \pm 0 \cdot 2 \%), \mathrm{C}_{17: 1} \omega 8 c(1 \cdot 0 \pm 0 \cdot 1 \%)$ and $\mathrm{C}_{18: 1} \omega 6 c(2 \cdot 9 \pm 0 \cdot 1 \%)$ were also detected. The DNA G $+\mathrm{C}$ content of strain FR1199 ${ }^{\mathrm{T}}$ was $39 \mathrm{~mol} \%$.

The formation of a distinctive phyletic line within the genus Pseudoalteromonas indicates that strain $\mathrm{FR} 1199^{\mathrm{T}}$ can be assigned as a novel species in this genus. In addition, a number of physiological and chemotaxonomic characters clearly distinguished our isolate from other phylogenetically related species (Table 1). Therefore, strain FR $1199^{\mathrm{T}}$ should be classified as a member of a novel species within the genus
Pseudoalteromonas, for which the name Pseudoalteromonas byunsanensis sp. nov. is proposed.

\section{Description of Pseudoalteromonas byunsanensis sp. nov.}

Pseudoalteromonas byunsanensis (by.un.san.en'sis. N.L. fem. adj. byunsanensis named after Byunsan, South Korea, the geographical origin of the type strain).

Cells are rod-shaped, $0 \cdot 5-0.8 \mu \mathrm{m}$ in diameter and $1 \cdot 5-2 \cdot 0 \mu \mathrm{m}$ in length, Gram-negative and motile. Strictly aerobic. Cells do not form endospores. Oxidase- and catalase-positive. Requires sea water for growth. Growth occurs in media with $0 \cdot 5-5 \%(\mathrm{w} / \mathrm{v}) \mathrm{NaCl}$, with the optimum at $1 \cdot 5-2 \%$. Temperature for growth ranges from 10 to $40{ }^{\circ} \mathrm{C}$, with the optimum at $25-30^{\circ} \mathrm{C}$. The $\mathrm{pH}$ for growth ranges from $5 \cdot 0$ to $10 \cdot 0$, with the optimum at $\mathrm{pH} 8 \cdot 0$. Colonies are colourless at $\mathrm{pH} \mathrm{5 \cdot 0}$ but violet-coloured at $\mathrm{pH}$ 6-10. Colonies are usually $2-3 \mathrm{~mm}$ in diameter within 3 days at $25{ }^{\circ} \mathrm{C}$. Does not reduce nitrate to nitrite. Produces gelatinase, cytochrome oxidase and aesculin dihydrolase, but not arginine dihydrolase, $\beta$-galactosidase, lysine decarboxylase, ornithine decarboxylase, urease, $\mathrm{H}_{2} \mathrm{~S}$, tryptophan deaminase, indole or acetone. Produces alkaline phosphatase, esterase (C4), esterase lipase (C8), leucine arylamidase, trypsin, 
acid phosphatase, naphthol-AS-BI-phosphohydrolase, $\alpha$ glucosidase and acid phosphatase, but not lipase (C14), cystine arylamide, valine arylamidase, $\alpha$-chymotrypsin, $\alpha$ galactosidase, $\beta$-galactosidase, $\beta$-glucuronidase, $\beta$-glucosidase, $N$-acetyl- $\beta$-glucosaminidase, $\alpha$-mannosidase, $\alpha$-fucosidase, lysine decarboxylase, ornithine decarboxylase or tryptophan deaminase. Utilizes the following substrates as sole carbon and energy sources: glucose, arabinose, mannose, mannitol, $\mathrm{N}$-acetylglucosamine, maltose and tetramethyl- $p$ phenylenediamine dichloride. Does not utilize the following substrates: gluconate, caprate, malate, malonate, citrate, phenylacetate and $p$-nitrophenyl $\beta$-galactopyranoside. Other phenotypic characteristics are given in Table 1 . The major cellular fatty acids are $\mathrm{C}_{16: 0}(27 \cdot 6 \pm 0 \cdot 4 \%), \mathrm{C}_{16: 1} \omega 7 c$ and/ or iso- $\mathrm{C}_{15: 0} 2-\mathrm{OH}(21 \cdot 7 \pm 1 \cdot 2 \%)$ and $\mathrm{C}_{18: 1} \omega 07 c(23 \cdot 3 \pm$ $0.5 \%)$. The DNA G $+\mathrm{C}$ content is $39 \mathrm{~mol} \%$.

The type strain, FR $1199^{\mathrm{T}}\left(=\mathrm{JCM} 12483^{\mathrm{T}}=\mathrm{KCTC} 12274^{\mathrm{T}}\right)$, was isolated from Korean tidal flat sediment.

\section{Acknowledgements}

This work was supported by the Korea Ministry of Science and Technology under National Research Laboratory Program (M10500000110-05J0000-11010) and the Brain Korea 21 Research Fellowship from the Ministry of Education and Human Resources Development.

\section{References}

Baumann, L., Baumann, P., Mandel, M. \& Allen, R. D. (1972). Taxonomy of aerobic marine eubacteria. J Bacteriol 110, 402-429.

Bowman, J. P. (1998). Pseudoalteromonas prydzensis sp. nov., a psychrotrophic, halotolerant bacterium from Antarctic sea ice. Int J Syst Bacteriol 48, 1037-1041.

Bozal, N., Tudela, E., Rosselló-Mora, R., Lalucat, J. \& Guinea, J. (1997). Pseudoalteromonas antarctica sp. nov., isolated from an Antarctic coastal environment. Int J Syst Bacteriol 47, 345-351.

Chun, J. \& Goodfellow, M. (1995). A phylogenetic analysis of the genus Nocardia with $16 \mathrm{~S}$ rRNA gene sequences. Int J Syst Bacteriol 45, 240-245.

Chun, J., Bae, K. S., Moon, E. Y., Jung, S. O., Lee, H. K. \& Kim, S. J. (2000). Nocardiopsis kunsanensis sp. nov., a moderately halophilic actinomycete isolated from a saltern. Int J Syst Evol Microbiol 50, 1909-1913.

Egan, S., Holmström, C. \& Kjelleberg, S. (2001). Pseudoalteromonas ulvae sp. nov., a bacterium with antifouling activities isolated from the surface of a marine alga. Int J Syst Evol Microbiol 51, 1499-1504.

Felsenstein, J. (1985). Confidence limits on phylogenies: an approach using the bootstrap. Evolution 39, 783-791.

Fitch, W. M. (1971). Toward defining the course of evolution: minimum change for a specific tree topology. Syst Zool 20, 406-416.

Fitch, W. M. \& Margoliash, E. (1967). Construction of phylogenetic trees. Science 155, 279-284.

Gauthier, M. J. (1976). Alteromonas rubra sp. nov., a new marine antibiotic-producing bacterium. Int J Syst Bacteriol 26, 459-466.

Gauthier, M. J. (1977). Alteromonas citrea, a new gram-negative, yellow-pigmented species from seawater. Int J Syst Bacteriol 27, 349-354.
Gauthier, M. J. (1982). Validation of the name Alteromonas luteoviolacea. Int J Syst Bacteriol 32, 82-86.

Gauthier, M. J. \& Breittmayer, V. A. (1979). A new antibioticproducing bacterium from seawater: Alteromonas aurantia sp. nov. Int J Syst Bacteriol 29, 366-372.

Gauthier, G., Gauthier, M. \& Christen, R. (1995). Phylogenetic analysis of the genera Alteromonas, Shewanella, and Moritella using genes coding for small-subunit rRNA sequences and division of the genus Alteromonas into two genera, Alteromonas (emended) and Pseudoalteromonas gen. nov., and proposal of twelve new species combinations. Int J Syst Bacteriol 45, 755-761.

Holmström, C., James, S., Neilan, B. A., White, D. C. \& Kjelleberg, S. (1998). Pseudoalteromonas tunicata sp. nov., a bacterium that produces antifouling agents. Int J Syst Bacteriol 48, 1205-1212.

Isnansetyo, A. \& Kamei, Y. (2003). Pseudoalteromonas phenolica sp. nov., a novel marine bacterium that produces phenolic antimethicillin-resistant Staphylococcus aureus substances. Int J Syst Evol Microbiol 53, 583-588.

Ivanova, E. P., Chun, J., Romanenko, L. A., Matté, M. E., Mikhailov, V. V., Frolova, G. M., Huq, A. \& Colwell, R. R. (2000). Reclassification of Alteromonas distincta Romanenko et al. 1995 as Pseudoalteromonas distincta comb. nov. Int J Syst Evol Microbiol 50, 141-144.

Ivanova, E. P., Kiprianova, E. A., Mikhailov, V. V., Levanova, G. F., Garagulya, A. D., Gorshkova, N. M., Yumoto, N. \& Yoshikawa, S. (1996). Characterization and identification of marine Alteromonas nigrifaciens strains and emendation of the description. Int J Syst Bacteriol 46, 223-228.

Ivanova, E. P., Kiprianova, E. A., Mikhailov, V. V. \& 9 other authors (1998). Phenotypic diversity of Pseudoalteromonas citrea from different marine habitats and emendation of the description. Int J Syst Bacteriol 48, 247-256.

Ivanova, E. P., Romanenko, L. A., Matté, M. H. \& 10 other authors (2001). Retrieval of the species Alteromonas tetraodonis Simidu et al. 1990 as Pseudoalteromonas tetraodonis comb. nov. and emendation of description. Int J Syst Evol Microbiol 51, 1071-1078.

Ivanova, E. P., Shevchenko, L. S., Sawabe, T., Lysenko, A. M., Svetashev, V. I., Gorshkova, N. M., Satomi, M., Christen, R. \& Mikhailov, V. V. (2002a). Pseudoalteromonas maricaloris sp. nov., isolated from an Australian sponge, and reclassification of [Pseudoalteromonas aurantia] NCIMB 2033 as Pseudoalteromonas flavipulchra sp. nov. Int J Syst Evol Microbiol 52, 263-271.

Ivanova, E. P., Sawabe, T., Lysenko, A. M., Gorshkova, N. M., Hayashi, K., Zhukova, N. V., Nicolau, D. V., Christen, R. \& Mikhailov, V. V. (2002b). Pseudoalteromonas translucida sp. nov. and Pseudoalteromonas paragorgicola sp. nov., and emended description of the genus. Int J Syst Evol Microbiol 52, 1759-1766.

Ivanova, E. P., Sawabe, T., Alexeeva, Y. V., Lysenko, A. M., Gorshkova, N. M., Hayashi, K., Zukova, N. V., Christen, R. \& Mikhailov, V. V. (2002c). Pseudoalteromonas issachenkonii sp. nov., a bacterium that degrades the thallus of the brown alga Fucus evanescens. Int J Syst Evol Microbiol 52, 229-234.

Ivanova, E. P., Sawabe, T., Lysenko, A. M. \& 8 other authors (2002d). Pseudoalteromonas ruthenica sp. nov., isolated from marine invertebrates. Int J Syst Evol Microbiol 52, 235-240.

Ivanova, E. P., Gorshkova, N. M., Zhukova, N. V., Lysenko, A. M., Zelepuga, E. A., Prokof'eva, N. G., Mikhailov, V. V., Nicolau, D. V. \& Christen, R. (2004). Characterization of Pseudoalteromonas distinctalike sea-water isolates and description of Pseudoalteromonas aliena sp. nov. Int J Syst Evol Microbiol 54, 1431-1437.

Jeon, Y. S., Chung, H., Park, S., Hur, I., Lee, J. H. \& Chun, J. (2005). jPHYDIT: a JAVA-based integrated environment for molecular phylogeny of ribosomal RNA sequences. Bioinformatics 21, 3171-3173. 
Jukes, T. H. \& Cantor, C. R. (1969). Evolution of protein molecules. In Mammalian Protein Metabolism, pp. 21-132. Edited by H. N. Munro. New York: Academic Press.

Kobayashi, T., Imada, K., Hiraishi, A., Tsujibo, H., Miyamoto, K., Inamori, Y., Hamada, N. \& Watanabe, E. (2003). Pseudoalteromonas sagamiensis sp. nov., a marine bacterium that produces protease inhibitors. Int J Syst Evol Microbiol 53, 1807-1811.

Kovacs, N. (1956). Identification of Pseudomonas pyocyanea by the oxidase reaction. Nature 178, 703 .

Lyman, J. \& Fleming, R. H. (1940). Composition of sea water. J Mar Res 3, 134-146.

Marmur, J. \& Doty, P. (1962). Determination of the base composition of deoxyribonucleic acid from its thermal denaturation temperature. J Mol Biol 5, 109-118.

Novick, N. J. \& Tyler, M. E. (1985). Isolation and characterization of Alteromonas luteoviolacea strains with sheathed flagella. Int J Syst Bacteriol 35, 111-113.

Romanenko, L. A., Lysenko, A. M., Mikhailov, V. V. \& Stepanenko, V. I. (1995). A new species of melanin-producing bacteria of the genus Alteromonas. Microbiology (English translation of Mikrobiologiia) 64, $74-77$.

Romanenko, L. A., Zhukova, N. V., Rohde, M., Lysenko, A. M., Mikhailov, V. V. \& Stackebrandt, E. (2003a). Pseudoalteromonas agarivorans sp. nov., a novel marine agarolytic bacterium. Int J Syst Evol Microbiol 53, 125-131.
Romanenko, L. A., Zhukova, N. V., Lysenko, A. M., Mikhailov, V. V. \& Stackebrandt, E. (2003b). Assignment of 'Alteromonas marinoglutinosa' NCIMB 1770 to Pseudoalteromonas mariniglutinosa sp. nov., nom. rev., comb. nov. Int J Syst Evol Microbiol 53, 1105-1109.

Saitou, N. \& Nei, M. (1987). The neighbor-joining method: a new method for reconstructing phylogenetic trees. Mol Biol Evol 4, 406-425.

Sawabe, T., Makino, H., Tatsumi, M., Nakano, K., Tajima, K., Iqbal, M. M., Yumoto, I., Ezura, Y. \& Christen, R. (1998). Pseudoalteromonas bacteriolytica sp. nov., a marine bacterium that is the causative agent of red spot disease of Laminaria japonica. Int J Syst Bacteriol 48, 769-774.

Sawabe, T., Tanaka, R., Iqbal, M. M., Tajima, K., Ezura, Y., Ivanova, E. P. \& Christen, R. (2000). Assignment of Alteromonas elyakovii KMM $162^{\mathrm{T}}$ and five strains isolated from spot-wounded fronds of Laminaria japonica to Pseudoalteromonas elyakovii comb. nov. and the extended description of the species. Int J Syst Evol Microbiol 50, 265-271.

Swofford, D. L. (1998). PAUP* - Phylogenetic Analysis Using Parsimony, version 4. Sunderland, MA: Sinauer Associates.

Venkateswaran, K. \& Dohmoto, N. (2000). Pseudoalteromonas peptidolytica sp. nov., a novel marine mussel-thread-degrading bacterium isolated from the Sea of Japan. Int J Syst Evol Microbiol 50, 565-574.

ZoBell, C. E. (1941). Studies on marine bacteria. I. The cultural requirements of heterotrophic aerobes. J Mar Res 4, 42-75. 